\title{
Religião, religiões e conceitos sociológicos: notas críticas sobre a hermenêutica normativa da religião
}

\author{
Religion, religions and sociological concepts: \\ critical notes on the normative hermeneutics of religion
}

Emerson José Sena da Silveira*

Resumo: Este artigo, a partir de reflexões antropossociológicas, pretende analisar as mútuas influências entre o campo religioso e a sociedade a partir de algumas dinâmicas empíricas. São tecidas críticas aos usos semânticos de algumas categorias. Empreende também, esboços de releitura de algumas análises sociológicas clássicas do religioso. Trazendo alguns exemplos empíricos de fenômenos religiosos contemporâneos, conclui-se que é necessário, por outras vias de abordagem, compreender as interações entre os fenômenos religiosos contemporâneos e as vertiginosas mudanças sociais. Outros percursos de compreensão epistemológica podem auxiliar os estudiosos da religião a lançar novas luzes sobre as dinâmicas da religião.

Palavras-chave: Religião; semântica; fenômenos religiosos

* Professor do Departamento de Ciência da Religião da UFJF e do Programa de Pós-Graduação em Ciência da Religião (UFJF), Brasil E-mail: emerson.pesquisa@gmail.com 


\begin{abstract}
This article, from anthropological and sociological reflections, intends to analyze the mutual influences between the religious field and society from some empirical dynamics. We analyzed the semantic uses of some categories. Also, we present sketches of rereading's of some classic sociological analyzes of religion. We will bring some empirical examples of contemporary religious phenomena, concluding that it is necessary, by other means of approach, to understand the interactions between contemporary religious phenomena and great social changes. Other routes of epistemological understanding may help scholars of religion to shed new light on the dynamics of religion.
\end{abstract}

Keywords: Religion; Semantics; Religious phenomena

\author{
Lutar com palavras/É a luta mais vã./Entretanto \\ lutamos/mal rompe a manhã./São muitas, eu pouco. \\ Carlos Drummond de Andrade
}

\title{
Introdução
}

A partir de reflexões antropossociológicas, pretende analisar as mútuas influências entre o campo religioso e a sociedade a partir de algumas dinâmicas empíricas usadas como ilustrações, colocando-se em perspectiva o conceito de religiosidades mágicas e éticas, o impacto da modernidade sobre o religioso e as dinâmicas da produção de fronteiras identitárias.

Teço críticas aos usos semânticos de determinadas categorias para o campo das ciências que estudam a religião, entre as quais "religião". Com essa perspectiva crítico-analítica, empreende esboços de releitura de algumas análises sociológicas clássicas do religioso.

Trazendo alguns exemplos de fenômenos religiosos contemporâneos, conclui-se que é necessário, por outras vias de abordagem, compreender as interações entre os fenômenos religiosos contemporâneos e as mudanças sociais. Faz-se necessário propor outros percursos de compreensão epistemológica. Novas perspectivas podem auxiliar os estudiosos da religião a lançar novas luzes sobre as dinâmicas empíricas dos fenômenos religiosos. Assim, a partir de reflexões teóricas, somadas a exemplos empíricos, pretende-se questionar alguns usos acadêmicos, e o douto senso.

Há que se investigar as perspectivas nas quais o religioso, em suas variadas dimensões, rito, valor, crenças, práticas, agentes e instituições, trava relação com as dimensões sociais, dotadas também de crenças, valores, agentes e instituições. 


\section{Da religião às religiões: repercussões e dinâmicas histórico- antropológicas}

Numa assunção natural do singular, os títulos de muitos estudos de religião (o sagrado, a igreja, a seita), levam à reflexão sobre a guerra filosófica "nietzschiana" contra a metafísica: ao longo da história humana na sociedade ocidental, é impossível ignorar que, no interior mesmo das redes de linguagens travadas nos discursos das ciências sociais, o sujeito gramatical foi tomado de forma naturalizada como sujeito ontológico. As análises sociológicas da religião, para enfrentar o desafio posto pelas metodologias objetivistas das Ciências Naturais, penderam para um horizonte normativo e reducionista. Em outras palavras, a sociologia, ao estudar a religião, tendeu a toma-la como máscara, ideologia, símbolo ou representação de uma outra realidade, social, por suposto, mas que seria, normativamente, mais profunda, autêntica e verdadeira.

Trata-se de uma argumentação que deve ser compreendida no confronto contra metafísica, especialmente a moderna, diante de três frentes de combate: sujeito moderno, fundacionismo, fim-da-metafísica pelo positivismo. Religião, cultura, Igreja e seita, que entremeiam as construções gramaticais de muitos textos históricos, sociológicos e teológicos como sujeitos no singular, acabam, no decorrer dos usos das ideologias e regimes de crença, transformando-se em ontologias, dogmáticas ou transcendentais, esquecidas de suas origens necessariamente plurais, complexas e históricas.

A perspectiva normativa, presente nas análises sociológicas da religião, cambaleou na esteira da crítica pós-moderna ${ }^{1}$ e foi acusada de ser insuficiente em suas pretensões hermenêuticas de dar conta de "explicar" a religião. As atuais reflexões apontam para o fato de que, numa época de fluxos migratórios e diaspóricos de pessoas, mercadorias e ideias, nunca foi tão fácil confundir o lugar que as pessoas ocupam com suas práticas religiosas e culturais, com o lugar onde se pensa ou se deseja que elas estejam. Diante desse cenário, os intérpretes e as fórmulas epistemológicas foram desinvestidos de plausibilidade, relidos e ressemantizados, espraiando-se por redes culturais de pesquisa, experiência e crença².

A época moderna, com suas acelerações, mudanças na estrutura de produção reprodução social, inaugurou a era das mobilidades, em especial a partir dos EUA, mas que progressivamente expande-se pelo mundo ocidental, a partir quatro tipos de mobilidade: a geográfica, a social, a conjugal e a política ${ }^{3}$. Essas mobilidades afetaram a distribuição e a correlação de forças no campo religioso brasileiro ${ }^{4}$. Novas forças religiosas emergiram com vigor (pentecostalismo e neopentecostalismo) ${ }^{5}$, antigas forças (catolicismo) viram-se pressionadas a mudar suas estratégias e a pluralizar-se, em termos de estilos, valores e rituais ${ }^{6}$. Pode-se pensar em novas formas de relação entre as religiões e a sociedade, a partir do aumento dessas mobilidades, inclusive, as interferências 
das religiões no espaço público.

Diante de inúmeros exemplos da relação entre as ordens do religioso e do social, uma das indagações pode versar sobre a maior ou menor interferência sobre o social, na vida sociopolítica das sociedades como um todo e da brasileira em particular, comparando-se ou não com outras épocas históricas. Uma resposta sumária a esse questionamento poderia suscitar comparações sem parâmetros, exemplos descontextualizados, inúmeros dados estatísticos sem enraizamento metodológico, além de exemplos empíricos desproporcionais.

Com isso, perde-se de vista um fato básico de toda a sociologia do religioso, sendo a religião parte do social, entendido como totalidade das relações travadas na sociedade. Embora a perspectiva durkheimiana clássica afirme que a religião é o social, e o social é, em sua origem, religioso, essa hipótese não consegue explicar as complexas tramas entre religião e sociedade, ao contrário, reforça tautologias ainda comuns em muitas teorias nas ciências da religião ${ }^{7}$.

Deve-se partir de algumas premissas, entre as quais a de que o religioso não está fora do social ou das totalidades sociais que integram e estruturam uma sociedade. Se, por um lado, interferência supõe um conjunto de ações, motivos, agentes e estruturas senão ainda uma direção determinada e o vetorial da ação que influencia um campo ou um enquadramento sociorreligioso, por outro lado, pressupões que também se deva ler na direção oposta: a interferência do social na religião. Diante isso, a leitura só está completa se as duas direções de intercâmbios entre o religioso e o social são reciprocamente consideradas, aquilatadas e constantemente redimensionadas. ${ }^{8}$

Apesar dessa necessária reciprocidade, as perspectivas teóricas das ciências sociais precisam enfatizar que os arranjos sociais entre Estado, sociedade e religião são variáveis historicamente e não podem ser entendidos uniformemente a partir de leituras pouco sofisticadas das teses weberianas, por exemplo, ou de outros autores ${ }^{9}$. Por outro lado, as ciências da religião desconfiam de termos muito vagos, como o sagrado e seu poder heurístico e hermenêutico, para interpretar todas as relações entre o social e o religioso ${ }^{10}$. Dessa forma, em virtude de e até mesmo a despeito de esses termos pretenderem explicar tudo, nada explicam, ao final da investigação e da proposição normativa.

Assim, para fornecer uma via de compreensão, entre outras, da "fenomenicidade" entre o religioso e o social, a partir da sociologia clássica da religião, pretende-se refletir sobre as relações que se travam entre o social e o religioso. Entender a religião como sistema organizado de crenças, práticas, valores e religiosidade; com a religião como vivências e experiências dos sujeitos relativas a aspectos da dimensão religiosa; com a sociabilidade como estrutura e comportamentos socialmente estruturados e culturalmente orientadores, legítimos ou não, requer que se abandone de vez a ilusão 
recorrente de um fenômeno sólido e homogêneo.

Há muitas perspectivas que combinam desde fechamentos radicalizados em torno de supostas naturezas essencialmente religiosas e sociais do ser humano, determinando supostamente os caminhos por onde o religioso influencia os fatores sociais, até aberturas que enfatizam o caráter enredado da religião e do social. Ambas as posições são compartilhadas tanto por conservadores religiosos quanto por grupos sociais, ligados ou não a minorias discriminadas.

O religioso está, e se dá, sempre em tensão e relação com o social ${ }^{11}$. Primeiro, porque as fronteiras entre as duas esferas nunca estão fechadas, ao contrário, são incertas e tensas, mantêm-se em estado de contínua de negociação. Segundo, porque em nome de deus, de deuses, de princípios espirituais ou laicos, reivindica-se intervenção nos assuntos deste e do outro mundo, em variados graus de rejeição e aceitação dos campos político, econômico, moral, artístico e intelectual e do mundo religioso.

Para Weber ${ }^{12}$, o mundo religioso e o social das sociedades ocidentais seguiram um curso em que a racionalidade, entendida como comportamento que busca coerência e sistematicidade entre meios e fins, foi construída numa complexa interface entre gradações internas e afinidades interativas entre os mundos religiosos. Nas sociedades complexas, em que coexiste a pluralidade dos sistemas e mundos no mesmo espaço-tempo, o religioso tornou-se um desafio conceitual e metodológico. No atual contexto de interações entre os vários sistemas religiosos e sociais, as fronteiras estão borradas.

Cresce, de forma incessante, a listagem de intercruzamentos entre o religioso e o social. Num espaço de onze anos, a partir do ano dois mil, alvorecer do novo milênio cristão, os fatos a seguir arrolados mostram a complexidade do cenário: em suas pregações, pastores da Assembleia de Deus recorrem a filósofos conservadores justificando sua oposição ao Projeto de Lei sobre a homofobia ${ }^{13}$; amparadas pelo ensino religioso confessional, escolas municipais da cidade do Rio de Janeiro almejavam ensinar o criacionismo ${ }^{14}$; carismáticos e católicos lançam mão de explicações paracientíficas contra o aborto ${ }^{15}$; nos ambientes urbanos onde métodos de cura quântica articulam-se às teorias da Física e a propostas por comunidades ecológicas e solidárias, ocorrem feiras de marketing cristão e festivais new age ${ }^{16}$; religiosidades institucionalizadas fundam faculdades, como a faculdade de teologia umbandista ${ }^{17}$ e a faculdade espírita ${ }^{18}$; no ambiente virtual, prolifera o consumo tecnorreligioso, proliferam comunidades religiosas e gnoses eletrônicas; escritores, como Jim Pinkoski, escrevem livros de ficção cientifica cristã, ${ }^{19}$ gênero emergente inspirado em profecias bíblicas que já atingiu, nos EUA, quarenta milhões de exemplares comercializados. ${ }^{20}$

Engrossando a lista de exemplos, emergem investidas neoconservadoras (moderno-reacionárias) entre cientistas da religião tais como as reflexões 
sobre eventos, como o Wikileaks, e o pastor norte-americano Terry Jones, que cumpriu ameaças anteriores e ateou fogo no Alcorão, livro sagrado de xiitas e sunitas $^{21}$; na imprensa brasileira, surgem declarações inusitadas, como a de um juiz auxiliar da presidência do Conselho Nacional de Justiça: "Não enxergaria nenhuma diferença entre uma declaração feita por mim e uma declaração mediúnica, que foi psicografada por alguém"; ${ }^{22}$ deputados evangélicos tinham encaminhado projetos de lei, arquivados, para retirar o título de Padroeira do Brasil $^{23}$. Por outro lado, numa sessão do Congresso, em homenagem a Allan Kardec, um deputado espírita diz ter recebido um espírito ${ }^{24}$.

Diante desse transbordamento de fronteiras, há duas formas de realizar a tarefa de interpretação: enfocar os fenômenos sob o cânone epistemológico clássico da modernidade, identificar invasões e ultrapassagens indevidas e ilegítimas, exigindo, portanto, procedimentos de restauração e diferenciação de territórios; ou operar uma nova leitura, deixando de ver a ambiguidade como um defeito, uma operação metodológica impura para, assim, construir uma nova narrativa epistemológica.

Vista como a mais fundamental para a compreensão moderno-científica, a tarefa de conceituar torna-se extenuante e infrutífera, na medida em que os contornos nunca são suficientemente nítidos para adquirirem consensos sólidos. Se a conceituação define zonas claras e delimitadas, logo surgem fenômenos que desestabilizam as fronteiras, iniciando-se uma nova tarefa de conceituação ${ }^{25}$. Por entre os dedos do conceito, o líquido da religião, da modernidade e do religioso, escapa constantemente. Talvez seja o caso de opor ao conceito a noção de narrativa, mais aberta e porosa, o que não significa menos rigor intelectual compreensivo.

Por outro lado, sempre provisórios e escapando das teorias com facilidade, os consensos desmancham-se. As linhas de tensão entre as ordens deste mundo e as religiões caracterizam-se por invasões, ultrapassagens, concessões e adaptações, num desenho multiforme caracterizado pela racionalidade tanto na religiosidade quanto nas ordens deste mundo; tanto no tipo de agrupamento, aristocracia da salvação, quanto nas plebes ou massas religiosas. ${ }^{26}$

\section{Alguns aspectos sociológicos da religião}

Weber $^{27}$ criou muitas categorias típico-ideais como uma espécie de índice de comparação e aproximação com o mundo empírico. Do argumento weberiano, podem-se deduzir dois tipos de religiosidade, a ética e a mágica, atreladas a aspectos mais ou menos enfáticos. Deve-se observar que, frequentemente no mundo real, as associações e correlações estabelecidas no tipo-ideal combinam-se entre si, em formas e graus variados. ${ }^{28}$

As tensões analisadas pela sociologia weberiana podem levar a posições 
de maior ou menor interferência nos mundos sociais. Assim, às religiosidades éticas podem-se alinhavar as variadas religiosidades em torno de algumas ideias: crença na transcendência do divino e na imanência do mundo em crescente oposição; a salvação como exigência de comportamento; normas e cultos escritos tendendo à burocratização; escrituras sagradas e sacerdotes e profetas como profissionais dos bens religiosos; éticas de negação do mundo ou de vontade de domá-lo ou submetê-lo; promessas de libertação do sofrimento; profetas e sacerdotes organizam comunidade morais e estruturas institucionais sacralizadas $^{29}$.

Às religiosidades mágicas atrelam-se características opostas: o mundo e o divino estão no mesmo plano e em crescente (com)fusão; a salvação é resultado de atos rituais, cultos, leis e regras de tradição oral; o feiticeiro e o mago oferecem serviços e operam com clientelas; as éticas são de aceitação do mundo.

Ambas as religiosidades não são fases ou etapas de uma linha contínua de evolução, como supôs a antropologia vitoriana, cabendo às religiões éticas o primeiro lugar na evolução. São formações que coexistem ou estão justapostas, e ainda, segundo alguns autores, mesclam-se, digladiam-se, imiscuem-se na vida empírica das igrejas, nos templos e grupos religiosos estando, simultaneamente, em relação, mais ou menos tensa ou porosa, com as ordens sociais deste mundo.

Ambas são formações que possuem graus e tipos de racionalidade distintos: enquanto as religiões mágicas caracterizam-se por racionalidade mais pragmática de cálculo e de barganha com os deuses, divindades e energias cósmicas, as religiosidades éticas caracterizam-se por uma racionalidade orientada pela coerência entre princípios e procedimentos ${ }^{30}$.

As religiosidades mágicas são altamente adaptativas aos mundos sociais do sexo, da arte, da economia, da política e da intelectualidade, ao contrário das éticas salvacionistas, que são organizadas em tipos ideais baseados na crescente tensão entre o grau de racionalidade interno e a esfera das religiosidades éticas. Segundo o argumento weberiano, à medida que as racionalidades internas a cada esfera se tornam autônomas, a tensão, os conflitos e as interferências entre a religiosidade e o social são maiores ${ }^{31}$.

Fuga e vontade de domar o mundo e a si próprio - dois tipos de comportamento ligados a dois conceitos clássicos - ascetismo e misticismo, emergem. São dimensões que os homens e mulheres imergem, buscando outro mundo no além, ou conquistando este mundo secular em nome do céu ${ }^{32}$.

Ambos crescem no solo das religiões de salvação, tanto ocidentais quanto orientais, e deste solo brotarão com força crescente, em variadas combinações, desde o judaísmo ao puritanismo protestante ${ }^{33}$. Esse aspecto é visto por alguns como o ápice lógico-histórico da marcha triunfal da racionalidade desencantada e a afinidade desta com as ordens políticas do estado e do mercado, governadas 
por leis racionais e burocracias impessoais.

Sutil e sofisticado, o pensamento weberiano identifica tanto continuidades quanto mudanças e rupturas entre as religiosidades mágicas e éticas. Ao abordar as origens do ascetismo e do misticismo, lê-se:

Uma vez evoluídos para um modo de vida metódico, formavam o núcleo do ascetismo, bem como do misticismo, e que surgiram originalmente de pressupostos mágicos. As práticas mágicas foram feitas para despertar qualidades carismáticas ou para impedir sortilégios malignos. [...] Mesmo no umbral de seu aparecimento, o ascetismo já revelava a sua face de Jano: de um lado, a renúncia ao mundo, e, do outro, o domínio do mundo em virtude de poderes mágicos obtidos pela renúncia ${ }^{34}$.

Em geral, as religiosidades mágicas são orgiásticas, assistemáticas ou se tornam forças tradicionais adaptadas ao mundo, ao contrário das religiosidades de salvação, que secretam um comportamento metódico, continuado e racional. Isso, aos olhos weberianos, consiste em verdadeira força social, capaz de constituir um desvio a alterar as linhas pelas quais a locomotiva dos interesses materiais e sociais trafega nas sociedades humanas.

O problema das interpretações evolucionárias do pensamento weberiano é atribuir uma linha férrea de desenvolvimento, de fio a pavio, na marcha histórica das sociedades e das formações religiosas, constituídas de aparatos institucionais e experimentações vivenciais, mediadas por conjuntos de valores, crenças e práticas. Tal noção é apropriada por variadas teorias da secularização, estabelecendo proximidades sociológicas e relações causais entre os processos sociais de modernização, secularização, desencantamento e diferenciação de esferas institucionais e o declínio da interferência das igrejas e instituições religiosas no ordenamento da vida social. A marcha acelerada da vida social rumo à intimidade da família e do sujeito era não só suposta, mas defendida.

A marcha histórica é irônica, subvertendo constantemente os esquemas teleológicos dos inúmeros pensadores laicos, ateus e teológicos que procuram, a todo custo, aprisionar a realidade na jaula de ferro do desenvolvimento lógico e abstrato do conceito e do sentido ${ }^{35}$. Essa marcha é para muitos um télos escondido que precisa ser revelado, mas para a sociologia weberiana só pode ser vista com inteligibilidade retrospectivamente, quando os nexos de significação e as afinidades eletivas (termo da literatura alemã aclimatado por Weber) da época, serão compreendidos a partir da ferramenta típico-ideal, usada sempre como índice de contraste com as realidades empíricas.

A multiplicidade dos fenômenos de hibridação tornou evidente as falhas nas supostas cadeias causais entre secularização, modernidade e desencantamento do mundo. Entre esses fenômenos destacam-se: mobilizações 
religiosas por estados teocráticos (Revolução Islâmica no Irã em 1979); eleição de bancadas comprometidas com ideais de salvação e julgamento moral (Tea Party, Frente Parlamentar Evangélica ${ }^{36}$ ); marchas e eventos de massa religiosos $^{37}$; lutas ecorreligiosas contra o latifúndio e problemas ambientais, entre tantos outros exemplos de intercâmbios, pesos e contrapesos do religioso sobre o social e deste sobre o religioso.

Em virtude disso, há três situações da religião na modernidade em face do pluralismo de valores e de instituições: negociação cognitiva (perspectivas dialogais em virtude dos diferentes modos de viver, crer e pertencer), capitulação cognitiva (abandono da identidade em prol do espírito da época) e redução cognitiva (reafirmação orgulhosa da ortodoxia, fechada sobre si mesma ou engajada em uma cruzada de conversão) ${ }^{38}$. Cada uma dessas situações dará origem a posturas e comportamentos frente às outras esferas do social: campos da sexualidade, política, economia, estética e intelectualidade. Em cada campo, as religiosidades éticas e mágicas terão linhas de atuação diferentes, mais tensas ou mais acomodadas, em virtude tanto de suas dinâmicas internas quanto das dinâmicas internas a cada esfera de valor.

Aqui, o cansaço da teoria clássica da secularização ${ }^{39}$ é evidente quer seja pela efervescência do religioso, quer seja pela recolocação de novos termos na pretensa equação homogênea que assumia jubilosamente a secularização. Modernidade, avanço social e religiosidade estão, portanto, inevitavelmente ligados de múltiplas formas e em variadas combinações entre as esferas estatal, pública e privada em todos os contextos históricos no mundo ocidental.

É preciso lançar novas vozes na arena, entre as quais as reflexões de Casanova ${ }^{40}$ propondo uma singular teoria da secularização que critica e articula três proposições diferentes, irregulares e não integradas: secularização como diferenciação de esferas seculares das instituições e normas religiosas; secularização como declínio das crenças e práticas religiosas; secularização como marginalização da religião para a esfera privada.

A partir da avaliação de cada uma delas, Casanova ${ }^{41}$ afirma que, embora a tese mais plausível da secularização seja a de diferenciação funcional, ressalta que a diferenciação funcional entre esferas seculares e religiosas permite a emergência de movimentos e de grupos de pressão religiosos - ou de "religiões públicas" - para disputar espaço, poder e recursos com grupos seculares na esfera pública. A seu ver, portanto, a diferenciação funcional não implica necessariamente o confinamento das religiões à esfera privada, o que impõe limites tanto à secularização societária quanto à do Estado e da política.

Sob esse aspecto, para compreender o campo religioso brasileiro, é preciso repensar o paradigma clássico da secularização, demonstrando que a religião católica operou como modelo e referência para a formulação de direitos e enquadramento das práticas mágico-populares como práticas religiosas ${ }^{42}$. $\mathrm{O}$ pluralismo religioso seria, pois, decorrente, entre outros fatores, de um processo 
histórico de controvérsias sobre práticas de cura, de feitiçaria e de possessão, implicando a "invenção" de novas religiões.

Esse processo de interação com outros fatores econômicos e sociais direciona fluxos de pessoas pela (re)criação dos desejos e das necessidades. Dessa forma, a inevitável interação entre dimensões sociais, como arte, consumo e religião, produz "máquinas desejantes", mediadas pela multiplicação "agônica" de imagens, metamorfoseadas em mil formas, fragmentando-se continuamente.

A condição de fetiche da mercadoria, ou seja, a condição de incorporação da religiosidade com seu aparato de festas, tradições populares, patrimônio ao consumo e à circulação está na raiz de novas formas de interface entre o religioso e o social.

Com o advento da era da imagem, quando igrejas e grupos religiosos lançam-se nas mídias intercomunicacionais e na moderna linguagem da propaganda para divulgar suas propostas a uma multidão de indivíduos, a religião desterritorializa-se, na medida em que legitima a lógica da espetacularização: seus temas e valores tornam-se espetáculos bons para serem olhados e consumidos. Suas imagens são expropriadas de seu território original, o solo da moral e da regulação dos comportamentos.

Dentro desse amplo processo de mudança, é certo que, paulatinamente, a religião institucional declina, e as regras tradicionais são enfraquecidas, produzindo o

fim do monopólio que a instituição possuía na promoção e no controle dos bens religiosos, particularmente das crenças [...] elas não são mais controladas e controláveis pela instituição, nem mesmo em seu próprio interior, como ensinam as peripécias da teologia católica ${ }^{43}$.

A individualização da esfera religiosa rege a adesão e a experimentação, nos mais diversos credos religiosos, sobrepondo e articulando-se, de forma tensa, à tradição, a herança e a obrigação. Contudo, a ideia de tradição, comunidade e herança serão, paradoxalmente, reivindicadas e reinventadas nas comunidades religiosas do ciberespaço, mas também, na vida social cotidiana.

Por outro lado, os mecanismos clássicos da democracia, da sociedade e do aparelho estatal também entram em crise na modernidade moderna: trabalho, partidos, sindicatos, entre outros, atingem a forma como a identidade social lastreada em uma concepção cartesiana e na filiação e participação contínua nos aparelhos e agências da sociedade, na integração às grandes narrativas (políticas, estéticas, religiosas) - vinha sendo formatada, desde o nascimento do Estado Nação moderno. A participação, os mediadores e os vínculos entre crer, pertencer e agir tende a dispersão e a pluralização semântica, simbólica e concreta. 
A própria noção de sujeito moderno (racional, unívoco e autocentrado) entrou em colapso, fragmentando-se em uma miríade de definições disputadas por grupos bem delineados de intelectuais, quais sejam: iluministas, modernos e pós-modernos ${ }^{44}$. Mas, com razão, pergunta-se: que sujeito é esse, iluminista, sociológico ou "pós-moderno", que empreende opções e alinhava, em sua trajetória, religião, lazer e mundos sociais como consumo, mídia, luta política, entre outros? A despeito disso, há um consenso: o sujeito não é um dado natural, ensimesmado, mas relacional e relativo.

E quanto à religião, qual a identidade nos tempos de hoje? A proposta de experimentar que oscila entre o individualismo e o holismo, numa tensão específica da cultura brasileira, atravessa a religião ${ }^{45}$. Enquanto o segundo polo é familial, pessoal e hierárquico, o primeiro é singular, impessoal, moderno e democrático.

Embora hoje se façam escolhas e experiências de maneira individualizada, isso não quer dizer que a comunidade e a instituição foram dispensadas, pelo contrário, os laços entre indivíduo e instituição, tradição e modernidade foram reorganizados em torno de um eixo sincrético, realizando a imbricação, não sem conflitos, entre essas polaridades aparentemente inconciliáveis.

Esse amplo espectro de transformações relaciona-se ao processo civilizacional que transferiu ao indivíduo a autoridade e legitimidade de empreender escolhas entre ideias, valores e comportamentos, fazendo da "experiência religiosa (...) uma experiência emocional, ligada ao sentimento, ao corpo e à subjetividade" ${ }^{46}$.

Dessa forma, nas sociedades informacionais, o mercado e a sociedade tendem a se organizar em torno da competitividade, da inovação, da organização em rede, das tecnologias informáticas e das formas precárias de trabalho. Essa nova configuração social é acompanhada por mudanças no foco de abordagem, de macroprocessos rumo a microprocessos, da estrutura ao sujeito, do social ao individual.

Concomitantemente, as práticas religiosas desinstitucionalizadas e o individualismo religioso junto a práticas políticas e rituais, dos mais variados matizes e combinações, crescem em amplos setores sociais, contribuindo para dinâmicas contraditórias: de um lado, destradicionalizações variadas e desregulações diversas; de outro, nostalgia e invenções de tradição, seguidas de fundamentalismos reemergentes e ressignificados, reivindicações de processos regulatórios nos campos religiosos brasileiro, latino-americano e europeu. Mesmo nos setores institucionalizados de práticas religiosas, as formas híbridas tendem a crescer.

\section{Novas buscas teóricas, velhos dilemas?}

A partir dessas considerações, é preciso frisar que a relação de trocas 
e influências mútuas entre modernidade social e religião é ambivalente e cambiante. Um dos sentidos radicados nessa ambiguidade é a noção clássica de que a modernidade e a religião são dimensões excludentes e conflituosas, dois reinos ou duas cidades (Santo Agostinho). Após o intenso processo de secularização vivido na segunda metade século XX em diante, acreditava-se que a Cidade dos Homens tinha enfim triunfado, mas essa vitória carregava em si a nostalgia da Cidade de Deus e a saudade do que nunca tinha sido experimentado: a plena a salvação e redenção.

Mas, contemporaneamente, na relação entre sociedade e religião, a religião parece irromper de dentro das próprias formas e linguagens da modernidade moderna, usando modernas estratégias para reivindicar a legitimidade de interferências, posições, críticas e defesas, confrontando suas próprias fronteiras, hibridizando-se. Talvez porque, na raiz da modernidade, quer seja movimentos religiosos, quer seja puritanismo ético, quer seja movimento seculares, quer seja positivismo, militância marxista ou direita reacionária compartilham de buscas similares por significados teleológicos.

É inegável a polêmica sobre qual será a atual configuração da religião: será o resultado do avanço da secularização ou a ressurgência da religião? Mas esssa própria forma de questionar é ainda uma forma de separar, ontologicamente, fronteiras que existem apenas em função de estratégias políticas da identidade moderna, pelo menos do que se acredita ser moderno. Embora se possa afirmar que a secularização tenha sido uma invenção do Projeto Moderno, tal como configurado nos mais diversos pensadores (Comte e Marx), para recriar fronteiras e estabelecer novos parâmetros sociais e culturais, ela se tornou refém da imanentização gnóstica.

Latour $^{47}$ analisa o fenômeno central do Ocidente, aquele que o distinguiria dos demais povos não-ocidentais: o Projeto Moderno, com todas as suas variações e estratégias epistemológicas e linguísticas. A marca central do Ocidente, defendida e teorizada, seria sua modernidade moderna, celebrandose, a partir de sua hegemonia histórica, a diferença ocidental em relação aos Outros $^{48}$.

E aqui, uma dupla estratégia de diferenciação foi construída: interna e externa às fronteiras culturais da modernidade moderna. Internamente, tentando-se manter separadas as díades religião e ciência, subjetivo e objetivo, natureza e cultura, e externamente, erigindo-se outras díades, como selvagem e civilizado, por exemplo ${ }^{49}$.

Num primeiro momento, quais seriam os fundamentos da produção científica da modernidade? Latour localiza-os a partir da análise de uma polêmica histórica ocorrida no século XVII, entre o filósofo Thomas Hobbes e o cientista Robert Boyle, ambos defendendo as fronteiras entre a Natureza e a Cultura, com políticas distintas, mas profundamente implicadas entre si, a política da ciência e a ciência da política ${ }^{50}$. 
Contudo, quanto mais o Projeto Moderno estabelecia essas divisões, mais cresciam os híbridos ${ }^{51}$. Durante o século XX e XXI, o crescimento dos híbridos e as constantes ultrapassagens de fronteiras questionaram a eficácia das estratégias modernas de demarcação ${ }^{52}$. Diga-se, de passagem, que todas as ciências, por um lado ou por outro, sacralizaram essas estratégias, e poucos pensadores, em certa medida, dissolveram essas oposições artificiais.

Vistas como "territórios ontológicos", essas fronteiras são artificiais ${ }^{53}$. A incomensurabilidade entre os mundos natural e social é desconstruída. Essa destruição da incomensurabilidade pode ser aplicada também à relação entre religião e sociedade. Assim é possível aplicar uma "antropologia simétrica" à religião e ao mundo social, a fim de desessencializar as diferenças, trazê-las para o plano da plurivocalidade semântica, ao invés de submetê-las a cânones epistemológicos dados a priori.

Nesse caso, a crítica de Latour atinge também a divisão de tarefas intelectuais, que foi hegemônica na modernidade:

A palavra "moderno" designa dois conjuntos de práticas totalmente diferentes, mas que recentemente deixaram de sê-lo. O primeiro conjunto de práticas cria, por "tradução", misturas entre gêneros de seres completamente novos, híbridos de natureza e cultura. O segundo cria, por "purificação", duas zonas ontológicas inteiramente distintas, a dos humanos [...] e os não-humanos [...] O primeiro conjunto corresponde àquilo que chamei de redes, o segundo ao que chamei de crítica [...] Em quanto considerarmos separadamente essas práticas, seremos realmente modernos, ou seja, estaremos aderindo ao projeto da purificação crítica, ainda que este se desenvolva somente através da proliferação dos híbridos [...] quanto mais nos proibimos de pensar os híbridos, mais seu cruzamento se torna possível; este é o paradoxo dos modernos $[\ldots]^{54}$.

A ideia de que os atores humanos e não humanos estão constantemente ligados a uma rede social de elementos (materiais e imateriais) é enfatizada ${ }^{55}$. A teoria do ator-rede é construída sob a perspectiva construtivista e baseada em conceitos e princípios: tradução e rede (comunicação e interligação entre todos os fatores e agentes) e princípio de simetria (os mesmos tipos de causas explicam as crenças verdadeiras e as crenças falsas). Emerge daí uma nova designação, a "antropologia simétrica" 56 .

No campo do pensamento antropológico, Barth $^{57}$ é o responsável pelo rompimento com as concepções essencialistas de identidade, ao estudar a forma como as etnias mobilizam memórias, emoções e recursos para estabelecerem quem é membro do grupo e quem não é. As etnias não são essências, mas 
intercâmbios permanentes em que forma-conteúdo e dentro-fora do círculo étnico constituem a matéria-prima da política identitária.

No processo de identificação, o principal elemento é a vontade de marcar os limites entre "eles" e "nós", traçando, portanto, uma fronteira. $\mathrm{Na}$ medida em que essa fronteira é o resultado de um compromisso entre o que o grupo pretende marcar e o que os outros querem designar-lhe, pode-se dizer que ela nasce do jogo de compromissos, sendo, portanto, social e simbólica. Desfaz-se a ambiguidade entre cultura e identidade.

A participação em uma determinada cultura não significa uma adesão automática a um tipo de identidade. As mesmas raízes culturais podem ser instrumentalizadas por determinados grupos ao ponto de construírem estratégias opostas de identificação. Esse jogo estratégico tem sido realizado atualmente pela esfera religiosa com outras esferas socioculturais, mobilizando intensamente recursos midiático-tecnológicos.

A análise barthiana pode ser aplicada tanto ao problema da religião na sociedade, quanto na investigação de como os atores religiosos estabelecem suas identidades em diálogo com os diversos mundos sociais. Por outro lado, ao abordar a questão das fronteiras lógicas e epistêmicas da modernidade, Bauman utiliza os termos liquidez/fluidez para descrever as relações travadas na sociedade atual ${ }^{58}$.

Dessa liquidez não escapa a religião, tanto no tocante à grande metanarrativa (dogma e tradição), quanto no tocante à pequena narrativa (trajetórias intersubjetivas). Derreter os sólidos, dissolver aquilo que persiste no tempo e está imune ao seu fluxo é o espírito da nova fase na história da modernidade ${ }^{59}$.

As fronteiras podem ser traduzidas como o esforço para sistematizar sensações e afetividades que, na corrosão efetivada pelos "poderes de solvência" da modernidade, multiplica os pontos de fuga, ratificando a metáfora deleuziana. No entanto, a alta modernidade, ou modernidade líquida, não é puro fluxo como um rio caudaloso sem margens, ou uma rede, sem nós e intercruzamentos.

Dessa forma, só é possível definir o local e sua fronteira através das características que se acredita poderem atribuir ao global: é "possível compreender a força do erro que o mundo moderno inflige a si mesmo" ao ignorar que os pares natural/social, local/global são adjetivos e não substantivos que designam regiões ontológicas de vida.

Pode-se dizer que os antimodernos (sólidos, conservadores, essencializadores), polo de oposição aos modernos (líquidos, corrosivos, desessencializadores), caíram no conto do vigário:

Que o Ocidente racionalizou e desencantou o mundo, que ele realmente povoou o social com monstros frios e racionais que estariam saturando todo o espaço, que ele transformou 
de vez o cosmos pré-moderno em uma interação mecânica de matérias puras. Mas, ao invés de ver nisto, como os modernizadores, conquistas gloriosas, ainda que dolorosas, $\mathrm{o}$ antimodernos veem nisto uma catástrofe sem igual ${ }^{60}$.

Os próprios polos de oposição, modernos e antimodernos, são, na prática, invenções. Dessa forma, nomear determinados movimentos religiosos como modernos, quanto à forma como usam os instrumentos de comunicação, e antimodernos, quanto ao conteúdo, não é constatar uma essência presente nas relações da religião católica com os mundos sociais do seu entorno. Essa nomeação é parte de um jogo, de uma busca identitária, um efeito da interação religioso-social e um instrumento de poder, de contenção de hibridizações.

Essas oposições acima mencionadas alimentam-se de si mesmas, mais do que das realidades às quais atribuem essência e movimentação. Os modernos, os antimodernos e os pós-modernos acusam-se de transgredir as fronteiras: "A defesa da marginalidade supõe a existência de um centro totalitário. Mas, se este centro e sua totalidade são ilusões, o elogio das margens é ridículo". ${ }^{61}$

Latour $^{62}$ pretende diminuir o fosso da incomensurabilidade entre as dimensões da realidade social/natural, ao afirmar que não se vive em

uma sociedade moderna porque, contrariamente a todas as outras, estaríamos enfim livres do inferno das relações coletivas, do obscurantismo da religião, da tirania da política, mas porque, da mesma forma que todas as outras redistribui as acusações, substituindo uma causa-judiciária, coletiva, social, por uma causa - científica, não social.

Por fim, para conter o esboroamento dos conceitos e da relação entre religião e sociedade, seria preciso pensar novas formas políticas de representação, uma nova forma de democracia que consiga fazer o trabalho de tradução entre as dimensões da religião e da sociedade.

Com isso é possível uma antropologia focada nas sociedades complexas que traga outras formas de perceber o religioso e seus processos de desdiferenciação e influência sobre o social em face à modernidade, ao observar a ação e a prática dos "cientistas nativos" ou dos "nativos-observadores", termos entendidos como construções provisórias e a posteriori ${ }^{63}$.

Para completar o rápido esboço feito sobre os caminhos e descaminhos da influência do religioso sobre o social, é preciso mencionar os processos de mundialização, comumente chamados de globalização.

Embora o crescimento e a globalização econômico-financeira, em complexo compasso-descompasso com a globalização cultural, e os consequentes fluxos derramados sobre a religião, e desta para a economia e a cultura, gerem e multipliquem precariedades, geram também novas dinâmicas 
e modelos.

A cultura digital, o midiativismo e as estratégias de apropriação de ferramentas tecnológicas das redes, como o Facebook, Twitter e outras, para causas e objetivos próprios, fazem com que sejam implodidas e explodidas dicotomias e distinções tradicionais entre fenômenos culturais e religiosos. $\mathrm{Se}$ as fronteiras não existissem, seria necessário inventá-las, diriam os neoconservadores.

Vale lembrar uma crítica fundamental ao borramento das fronteiras, diante das indistinções de entradas e saídas dos campos científicos e religiosos, ao mirar o exemplo de bispos psicanalistas: diante da argumentação de que saíram do campo, mas de lá não arredaram o pé, o sociólogo francês faz uma salutar advertência: só por uma radical objetivação dos engajamentos ocultos e indistintos é possível acabar com o uso ilegítimo, em termos metodológicos e epistemológicos, da dupla filiação - religião e ciência ${ }^{64}$.

Por essas e outras, diante das novas dinâmicas inventadas e experimentadas "fora do eixo" das interpretações autorizadas e das instâncias que as chancelam, desde a esquerda política clássica, às instâncias teológicas e sociológicas do pensamento ortodoxo, nas ciências em geral, e nas ciências da religião em particular, emergem receios e tensões.

Como os arranjos sociais e institucionais mudam, e as convenções conceituais parecem não dar conta, exigem-se releituras, ressignificações, renovações de conceitos tais como o de classe social, sagrado, profano e outros. Assim, não são sujeitos abstratos e universais que assistimos nas movimentações sociais e culturais, mas múltiplos atores em existência interessada, desde os exímios contra-ataques conservadores ou político-pentecostais conservadores, aos ecocristãos das classes médias da Europa às Américas.

Nas atuais dinâmicas culturais, emergem movimentos com dinâmica própria e singular em cada território, com uma pauta heterogênea, aberta e em construção, sem "central única" ou "comando" dos "iluminados", que se auto-organiza, e cujos "fins" não foram dados a priori. Trata-se, também, de arranjos transversais que agregam grupamentos, faixas etárias, profissões, religiosidades, "proletariedades" urbanas e forças de transformação no capitalismo contemporâneo, presentes nas estruturações culturais e religiosas.

As marchas e acampamentos (e tantos outros fenômenos) como base de um novo ativismo contemporâneo e a da emergência do "proletariado cognitivo" (uma reinvenção linguística de cunho marxista evidenciando o achatamento da intelectualidade) evidenciam que o sistema trabalhista clássico, fordista e previdenciário, não dá mais conta da dinâmica do crescimento das ocupações livres (frágeis e inseguras).

Tal precariedade e tal autonomia não significam apenas triunfo e reemergência do poder pastoral, religioso ou secular, mas potência para novos arranjos, alianças e lutas, decorrência de potentes laboratórios de 
experimentação das novas dinâmicas das subjetividades, e suas lutas, na cultura, na sociedade e na religião.

A crítica a esse cenário é o ponto para o qual convergem tanto comunidades religiosas carismáticas e pentecostais quanto extremismos de esquerda e de direita, numa relação de rancor e desconfiança vinda, por um lado, de profecias religiosas de líderes buscando autossuficiência diante da iminente "queda deste mundo"; por outro lado, de crenças gnósticas e laicas no comunismo ainda vindouro ou na contemporânea liberalidade da mão do mercado.

No cenário contemporâneo, avizinha-se uma tensão aporética entre a postulada universalidade de demandas éticas e o policentrismo e polivocalidade de cada autoridade ética; entre o sentido moral prevalente e a evidência experimental de suas transgressões. Talvez esteja aí um dos campos mais delicados das tramas tensas entre experiências religiosas, transformações culturais e injunções do religioso sobre o social e deste sobre o religioso ${ }^{65}$.

\section{À guisa de (in)conclusões}

Se Hervieu-Leger ${ }^{66}$ identificou, nas tradições religiosas, os especialistas que as guardam como produtores da memória autorizada e legítima, como mantenedores da conexão entre o presente e o memorável passado, podem-se estender suas reflexões ao campo das ortodoxias institucionais científicas que estabelecem as condições válidas de interpretação dos fenômenos religiosos e das lutas pela obtenção da hegemonia de certas miradas no interior dos grupamentos e comunidades de cientistas da religião.

A autoevidência do religioso, do sagrado, do social, da razão e da ciência perdeu-se, precisando ser constantemente construída em meio aos eixos culturais, nos mais complexos enlaces: mídias de massa e cibernéticas, biotecnologias, neuropsico-genéticas, ecologias e pobrezas econômicas, gêneros e moralidades diversas.

Da forma como a religião esta situada no cenário contemporâneo, o último elo da relação entre o religioso e o social são os padrões de avaliação moral e os modos socioculturais de vivência, irremediavelmente ligados às contradições sociais e de gênero inscritas em complexos quadros de relação entre Estado, políticas públicas, movimentos religiosos, cívicos e socais e o mercado econômico.

Das culturas surgem os padrões que opõem o "nós" ao "eles": de um lado estão as ações moralmente consentidas, legítimas, no limite "humanas" que "nós" praticamos; do lado oposto, estão as ações espúrias e ilegítimas, no limite "não-humanas", que "eles" praticam. Eis o ponto nodal em que as religiões produzem os mais intensos embates no campo das sociedades laicas ocidentais, por vezes em relação tensa e ambígua, com outras comunidades 
culturais e políticas: com o Estado e com as ciências de modo geral.

Por outro lado, as práticas religiosas desinstitucionalizadas e o individualismo religioso junto a práticas políticas e rituais, dos mais variados matizes e combinações, crescem em amplos setores sociais, contribuindo para dinâmicas contraditórias: de um lado, destradicionalizações variadas e desregulaçãos diversas; de outro, nostalgia e invenções de tradição, seguidas de fundamentalismos reemergentes e ressignificados, reinvidicações de processos regulatórios nos campos religiosos brasileiro, latino-americano e europeu.

Expressas no singular, cultura e religião sinalizam utopia e anseio por uma totalidade abstrata passível de pleno entendimento, embora suas vivências reais estejam lastreadas no plural, nos fluxos e refluxos das estruturas políticas, econômicas e culturais da contemporaneidade.

À guisa de conclusão, recorre-se a duas propostas: historicizar os discursos produzidos nos mais variados locais (igrejas, comunidades científicas e de luta política), instrumentos e veículos (mídias de massa e cibernéticas) e agentes (intelectuais, religiosos, leigos) sobre cultura e religião; compreender dentro de que limites pensa e escreve uma sociedade que, nos contextos dos movimentos globalizatórios, é atravessada por novas formas de intertextualidades, de contato e economia, de comunicação e relação.

O desafio colocado pelo estudo do religioso nas atuais sociedades será a construção de uma condição dialógica que produza uma nova função comunicativa e um novo desempenho epistemológico no âmbito das ciências sociais da religião. Assim, é possível empreender a difícil tarefa da compreensão do religioso sem ser atropelado pelos "objetos-sujeitos" ou "sujeitos-objetos" das experiências, das estruturas e dos processos a serem investigados.

\section{Notas de Fim}

1 HALL, Stuart. A identidade cultural na pós-modernidade. 6. ed. Rio de Janeiro: DP\&A, 2001

2 MONTERO, Paula. Max Weber e os dilemas da secularização: o lugar da religião no mundo contemporâneo. Novos Estudos Cebrap, São Paulo, n. 65, p. 34-44, 2003; Idem. Religião, pluralismo e esfera pública no Brasil. Novos Estudos Cebrap, São Paulo, n. 74, p. 47-65, 2006.

3 WALZER, Michael. Política e paixão. São Paulo: Martins Fontes, 2008.

4 CAMURÇA, Marcelo. Entre sincretismos e "guerras santas": dinâmicas e linhas de força no campo religioso brasileiro. Revista USP, São Paulo, p. 173-185, março/maio de 2009.

5 ORO, Ari Pedro. O “neopentecostalismo" macumbeiro. REVISTA USP, São Paulo, n.68, p. 319-332, dezembro/fevereiro 2005-2006 e CAMPOS, Leonildo Silveira. As origens norteamericanas do pentecostalismo brasileiro: observações sobre uma relação ainda pouco avaliada. REVISTA USP, São Paulo, n.67, p. 100-115, setembro/novembro 2005.

6TEIXEIRA, Faustino. Facetas do catolicismo contemporâneo. Revista da USP, p.14-23, setembro/novembro 2005 
7 DURKHEIM, Emile. As formas elementares da vida religiosa. São Paulo: Martins Fontes, 2006.

8 CASANOVA, Jose. Public Religions in the Modern World. C Chicago, The University of Chicago Press, 1994.

9 Idem, ibidem.

10 USARSKI, Frank. Os enganos sobre o Sagrado. Uma síntese da crítica ao ramo "clássico" da Fenomenologia da Religião e seus conceitos-chave. REVER, Revista de Estudos da Religião. São Paulo, no 4, 2004, p. 73-95.

11 CAMURÇA, Marcelo. Op. Cit., 2009.

12 WEBER, Max. Rejeições religiosas do mundo e suas direções. In: WEBER, Max. Ensaios de Sociologia. 5. ed. Rio de Janeiro: LTC, 2002. p. 226-49.

13 Disponível em: $<$ http://congressoemfoco.uol.com.br/noticias/projeto-da-homofobia-opoegays-e-religiosos/>. Acesso em: 18 de abril de 2017.

14 Disponível em: <http://www1.folha.uol.com.br/folha/ciencia/ult306u11748.shtml >. Acesso em: 17 de abril de 2017.

15 MORAES, Renata Jost. As chaves do inconsciente. 23. Ed. Petrópolis: Vozes, 2006. Seja observado o número elevado de edições, indicando um grande número de leitores.

16 AMARAL, Leila. Nova Era: um movimento de caminhos cruzados. São Paulo: Paulinas, 1994

17 Disponível em: <http://noticias.universia.com.br/destaque/noticia/2004/01/13/525264/ primeira-faculdade-umbanda-abre-inscries-vestibular.html > . Acesso em 18 de abril de 2017.

18 Disponível em: < http://g1.globo.com/globo-reporter/noticia/2013/11/faculdade-espiritapesquisa-ha-30-anos-os-chamados-fenomenos-da-paranormalidade.html $>$. Acesso em $18 \mathrm{de}$ abril de 2017

19 Título: A Creationist's View of Dinosaurs and the Theory of Evolution.

20 O último best-seller desse ramo se chama "Gloriosa aparição", uma ficção em que o anticristo se encarna no secretário-geral da ONU, cria um governo único mundial, com uma única religião, e estabelece sua capital na bíblica Babilônia (Bagdá). São os sinais de que o Apocalipse está próximo e o verdadeiro Cristo voltaria à Terra, como um guerreiro furioso em violência sagrada.

21Disponível em: <http://oglobo.globo.com/mundo/pastor-americano-queima-alcoraopoliticos-iranianos-reagem-4778559>. Acesso em 18 de abril de 2017.

22 Essa declaração foi feita por Alexandre Azevedo e registrada no jornal Estado de São Paulo do dia 25 de maio de 2008.

23 Disponível em: <http://www2.camara.leg.br/camaranoticias/noticias/EDUCACAO-ECULTURA/118715-PROJETO-TORNA-NOSSA-SENHORA-PADROEIRA-APENAS-DOSCATOLICOS.html>. Acesso em 18 de abril de 2017.

24 Disponível em: <http://www1.folha.uol.com.br/fsp/brasil/fc2910200422.htm>. Acesso em 18 de abril de 2017.

25 LATOUR, Bruno. Jamais fomos modernos. Ensaio de antropologia simétrica. Rio de Janeiro: Ed. 34, 1994. 
26 BARTH, Frederic. Les groups ethniques et leurs frontières. In: POUTIGNAT, L.; STREIFFFENART, J. Théories de l'ethnicité. Paris: PUF, 1995; BARTH, Frédéric. O guru, o iniciador e outras variações antropológicas. Rio de Janeiro: Contra Capa Livraria, 2000.

27 WEBER, Max. Op. Cit., 2002, p. 226-49.

28 WEBER, Max. Sociologia das religiões (tipos de relações comunitárias religiosas). In: WEBER, Max. Sociologia da dominação. In: WEBER, Max. Economia e Sociedade. Vol. 1. Brasília: Editora Universidade de Brasília, p. 279-480, 1991.

29 WEBER, Max. Sociologia da Dominação. In: WEBER, Max. Economia e Sociedade. Vol. 2. Brasília: Editora Universidade de Brasília, p. 187-580, 1999.

30 WEBER, Max. Sociología de la Religión, Madrid: ISTMO, 1997.

31 Idem, ibidem.

32 Idem, ibidem.

33 Idem, ibidem.

34 WEBER, Max. Op. Cit., 2002, p. 229.

35 Idem, ibidem.

36 SURUAGY, Bruna. Religião e Política: ideologia e ação da "Bancada Evangélica" na Câmara Federal. Tese de Doutorado em Psicologia Social, PUC-São Paulo, 2011.

37 SANT’ANA, Raquel. O som da Marcha: evangélicos e espaço público na Marcha para Jesus. Religião e Sociedade, Rio de Janeiro, vol. 34, n. 2, p. 210-231, 2014

38 BERGER, Peter. Una gloria remota. Avere fede nell'epoca del pluralismo. Bologna: Il Mulino, 1994.

39 CASANOVA, Op. Cit., 1994.

40 Idem, ibidem.

41 Idem, ibidem.

42 MONTERO, Paula. Op. Cit., 2003 e 2006.

43 FIROLAMO, Giovanni; PRANDI, Carlo. As ciências das religiões. São Paulo: Paulus, 1999, p. 287.

44 LATOUR, Bruno. Jamais fomos modernos. Ensaio de antropologia simétrica. Rio de Janeiro: Ed. 34, 1994.

45 SANCHIS, Pierre. As tramas sincréticas da história. Revista Brasileira de Ciências Sociais, 28, 123-138, 1995.

46 ORO, Ari P. Considerações sobre a Modernidade Religiosa. Sociedad y Religión, n. 14/15, noviembre, p. 61-70, 1996, p. 66.

47 LATOUR, Bruno. Op. Cit., 1994.

48 Idem, ibidem.

49 Idem, ibidem.

50 Idem, ibidem.

51 Idem, ibidem. 
52 Idem, ibidem.

53 Idem, ibidem.

54 Idem, ibidem, p. 17.

55 Idem, ibidem.

56 Idem, ibidem.

57 BARTH, Frédéric. Po. Cit., 1995; BARTH, Frédéric. Op. Cit., 2000.

58 BAUMAN, Zygmunt. Modernidade líquida. Rio de Janeiro: Jorge Zahar, 2001; Idem. Vida a crédito: conversas com Citlali Rovirosa-Madrazo. Rio de Janeiro: Zahar, 2010.

59 Idem, ibidem.

60 LATOUR, Bruno. Op. Cit., 1994, p. 121.

61 LATOUR, Bruno. Op. Cit., 1994, p. 83.

62 Idem, ibidem.

63 Idem, ibidem.

64 BOURDIEU, Pierre. Os usos sociais da ciência. Por uma sociologia clínica do campo cientifico. São Paulo: UNESP, 2004.

65 ANGENOT, Marc. El discurso social: los límites históricos de lo pensable y lo decible. Buenos Aires: Siglo XXI Editores, 2010.

66 HERVIÉU-LÈGER, Daniele. La religion pour mémoire. Paris: Editions Du Cerf, 2003.

Artigo recebido em março de 2017. Aceito em maio de 2017. 